\title{
PENDAMPINGAN PENGRAJIN SANDAL DI TOYOMARTO KECAMATAN SINGOSARI KABUPATEN MALANG
}

\author{
Sri Andriani ${ }^{* *}$, Masyhuri Machfudz ${ }^{2}$ \\ ${ }^{1}$ Program Studi Akuntansi, UIN Maulana Malik Ibrahim, Malang \\ ${ }^{2}$ Program Studi Agribisnis, Fakultas Pertanian, Universitas Islam Malang \\ *Email Korespondensi: sriandriani@akutansi.uin.uin-malang.ac.id
}

Submitted : 12 November 2020; Revision : 15 Februari 2021; Accepted : 18 Februari 2021

\begin{abstract}
ABSTRAK
UKM kerajinan klompen/bakia dan sandal sepon sebagai home industri di Desa Toyomarto Singosari Malang, Jawa Timur berdiri sejak 1992. Produksi pemasarannya meliputi Jawa Tengah $(14 \%)$, Surabaya (26\%), Madura (10\%), Bali (10\%), Malang (20\%) dan sebanyak $10 \%$ dikirim ke ke Jepang (5\%) dan 5\% sisanya ke manca negara lainnya. Program pengabdian ini dilakukan dengan mitra kerja UKM "Darto" dan "H. Imam Syafi'i". Pendekatan yang dilakukan secara persuasif dan kesepakatan (agreement). Bahan baku pengrajin berasal dari desa setempat dan desa sekitarnya dengan kapasitas sebesar 80-100 gelondong, berupa kayu Sengon Mahoni, Basia, dan Jati. Produksi yang dihasilkan antara 75-110 buah setiap hari secara manual. Kegiatan pengabdian ini menciptakan peralatan berupa 'MAL' yaitu desain yang dilakukan dengan penggerak dinamo, oven bahan baku, kemasan produk, dan peningkatan skill tenaga kerja. Hasil kegiatan berupa produk rumah oven, 'MAL' dan pelatihan skill karyawan dengan berbagai produk yang telah dihasilkan ada peningkatan. Rekomendasi yang ditawarkan adalah pembinaan dan pendampingan perlu dilakukan secara intensif, karena ekonomi kreatif merupakan potensi untuk dapat dikembangkan lebih lanjut mulai dari hulu sampai ke hilir.
\end{abstract}

Kata kunci : Sandal, UKM, Ekonomi Kreatif, Home Industri.

\section{ABSTRACT}

Klompen/bakia handicrafts and sponge sandals as home industries in Toyomarto Village, Singosari, Malang, East Java, have been established since 1992, marketing is to Central Java (14\%), Surabaya (26\%), Madura (10\%), Bali (10\%), Malang (20\%) and as much as $10 \%$ is sent to others, namely to Japan (5\%) and around $5 \%$ to other countries. This service program is carried out with SME partners "Darto" and "H. Imam Syafi'i ". The approach is carried out with persuasion and agreement (agreement). The results of the program are raw materials from local villages and surrounding villages with a capacity of 80-100 logs, in the form of Sengon Mahoni, Basia, and Teak wood. Production is produced between 75-110 pieces per day manually. The opportunity for intervention is to create equipment in the form of ' $M A L$ ', namely designs that are carried out with dynamo drives, as well as raw material ovens, product packaging, increasing workforce skills. The results show that the home product is open, "MAL" and employee skills training with the various products. The recommendation offered is that guidance and assistance need to be done more intensively because this creative economy has the potential to be developed from upstream-downstream.

Keywords : Sandals, SME, Creative Economy, Home Industry.

\section{PENDAHULUAN}

Salah satu sentra industri kerajinan adalah kerajinan klompen/bakia dan sandal sepon yang merupakan home industri di Dusun Ngujung dan Dusun Sumberawan, Desa Toyomarto, Kecamatan Singosari, Kabupaten Malang, Jawa Timur. Kerajinan klompen/bakia yang ada telah diwarisi secara turun-temurun, sedangkan pembuatan sandal spon mulai pada tahun 1992. Seiring dengan berjalannya waktu, usaha tersebut sampai sekarang sudah berkembang. Eksistensi usaha ini karena supplai bahan baku yang cukup 
baik dan kontinyu (Andriani and Mu'is, 2017; Kusumandyoko and Abidin, 2017; Mansur, Machfudz and Widarko, 2017; Rofii, Hunaini and Tjahjono, 2018; Widiastuti and RS, 2018).

Sebagian besar pemasarannya ke Jawa Tengah (14\%), Surabaya (26\%), Madura (10\%), Bali (10\%), Malang (20\%) dan sebanyak 10\% dikirim ke kota lainnya di Indonesia. Selain itu, tidak jarang hasil karya pengrajin tersebut telah diekspor ke Jepang sebanyak (5\%) dan sekitar 5\% dikirim ke manca negara lainnya, meskipun hingga sekarang masih bersifat labil dan tidak kontinyu. Daerah Dusun Ngujung sampai saat ini jumlah pengusaha yang terdaftar sebanyak 17 pengusaha, sedangkan di Dusun Sumberawan terdapat sejumlah 30 pengusaha. Di Desa Tirtomoyo mempunyai potensi yang lain yaitu seperti pengrajin cobek batu, penambangan pasir, wisata Candi Singosari, wisata kebun the, meskipun belum merupakan sentra industri. Daerah obyek wisata berpotensi sebagai altenatif pasar produk (Kusumandyoko and Abidin, 2017; Rofii, Hunaini and Tjahjono, 2018; Widiastuti and RS, 2018).

Profil mitra kerja pada program ini dapat dijabarkan bahwa (Andriani and Mu'is, 2017; Mahfudz, 2020),

1. UKM "Darta" adalah bergerak dalam usaha klompen yang beralamat di Desa Toyomarto, RT-07 RW-03, Kecamatan Singosari, Kabupaten Malang, Jawa Timur. Usahanya dimulai pada tahun 1992 dengan ciri khas yang digunakan bernama 'PRODET'. Alasan UKM “Darto" dijadikan sebagai mitra adalah bahan baku yang selalu tersedia, produksi cukup banyak yaitu sekitar 50 pasang sandal, tenaga yang bekerja sebanyak 5-8 orang, akses pasar menjangkau sampai ke luar daerah dan telah melaksanakan pengiriman barang sebanyak 5 kali ke Jepang.

2. Usaha klompen yang beramat di Desa Toyomarto RT-06 RW-03, Kecamatan Singosari, Kabupaten Malang. Usahanya dimulai pada tahun 1992 dengan nama "YUSTA" atau UKM "Imam Syafi'i". Alasan UKM 'Imam Syafi'i' dijadikan mitra adalah bahan baku selalu tersedia bahkan $25 \%$ berasal dari tanaman miliknya sendiri, produksi cukup sebanyak yaitu sekitar 50-65 sandal, tenaga yang digunakan 9 orang termasuk tenaga kerja dari keluarga terdekat atau tetangganya, akses pasar menjangka ke luar daerah dan telah melaksanakan pengiriman barang sebanyak 7 kali ke Jepang, dengan rata-rata setiap pengiriman sebanyak 1500 pasang sandal.

Dari informasi dua mitra ini, telah dilakukan pendirian asosiasi antar pengrajian sandal yang diwadahi dalam paguyupan bernama "Sinar Mandiri".

\section{METODE}

Dari berbagai permasalahan prioritas yang sudah disepakati antara tim pengusul dan mitra UKM, maka ditawarkan dalam melakukan tata cara dan startegi pemecahan masalah setiap tahunnya sebagai berikut (Ennis and Litster, 1996; Kusumandyoko and Abidin, 2017; Mansur, Machfudz and Widarko, 2017; Widiastuti and RS, 2018; Mahfudz, 2020):

a. Membuat rumah oven yang dapat mendorong percepatan produksi khususnya dalam pengeringan kayu yang akan dilakukan percetakan model/desain, sehingga kapasitas produksi dapat meningkat. Selanjutnya dalam pelaksanaan desain yang awalnya dilakukan secara konvensional dapat diteruskan dengan menggunakan pengerak mesin. Estimasi hasil dari awal hingga pelaksanaa model ini akan dapat meingkatkan produk 3-4 kali lipat. Peng-MAL-an modifikasi hasil ini menjadikan supply dari permintaan yang meningkat tidak akan menunggu hingga 5-7 hari diestimasikan masa tunggu kurang dari 3 hari.

b. Efisiensi dari penangan produksi dapat terselesaikan mencapai $25 \%$, sehingga perlu dilakukan pelatihan dalam peningkatan skill para tenaga kerja. Langkah yang dilakukan dengan beberapa tahap; (i) pendidikan dengan menggunakan modul yang disesuaikan ipteks yang telah mereka miliki, (ii) pelatihan sebagai manisfestasi dari 
pendidikan dengan praktek langsung dengan control para trainer; (iii) pendampingan yaitu dilakukan kontrol dalam pelaksanaan hasil pendidikan dan pelatihan dalam setiap pekan agar kesesuai hasil dengan ukuran batas minimum.

c. Meningkatkan kemampuan SDM dalam hal job description sehingga operasional dapat dilakukan dengan baik dan bekerja secara profesional dari masing-masing tenaga kerja sehingga tidak bersifat serabutan.

d. Pendidikan, pelatihan dan pendampingan (P3) pada tenaga kerja dalam hal pembukuan untuk melakukan perencanaan anggaran produksi hingga anggaran pemasaran.

\section{HASIL DAN PEMBAHASAN}

\section{Bahan Baku}

Asal bahan baku yang digunakan dari tiga titik, yaitu Perhutani di Kecamtan Singosari, Kecamatan Karangploso dan Desa Toyomarto dan/atau tetangga desa. Jenis kayu yang digunakan adalah kayu lokal jenis Mahoni, Basia dan Jati. Tetapi hampir $75 \%$ bahan baku menggunakan kayu jenis Mahoni dan Basia.
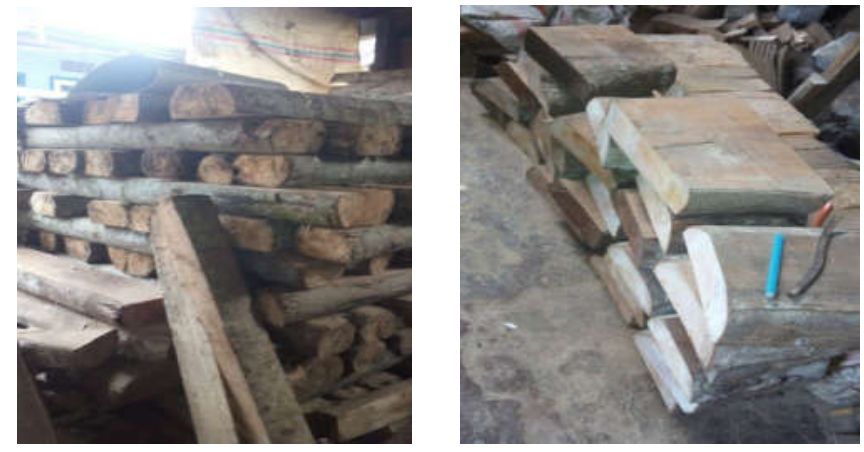

Gambar 1. Balok dari Kayu Sengon Mahoni dan Basia

Kapasitas supplai kayu sebagai bahan baku dilakukan setiap UKM yang membutuhkan 80-100 potong (gelondong) dengan ukuran masing-masing gelodong sepanjang $1 \mathrm{~m}^{2}$ dengan diameter $15 \mathrm{~cm}$. Permintaan semua UKM yang ada di desa ini sebanyak 15 UMK, mencapai 1500 gelondong per bulan. Spesifikasi bahan baku baik kayu Sengon Basia, Mahoni maupun kayu Jati telah berumur lebih dari 3 tahun. Hal ini dapat diindikasikan tingkat diameter kayu minimal $15 \mathrm{~cm}$. Kontinuitas pemenuhan bahan baku dapat terjamin, karena Perhutani selalu memberi bibit kayu Sengon kepada petani-petani dalam rangka program sengonisasi.

Bahan baku pembuatan klompen selain kayu adalah cat, lem, sepon, kain, paku pines, benang, amplas, soul alas dan kulit. Semua bahan selain kayu ini diestimasi sekitar $40 \%$ dari keseluruhan bahan yang dibutuhkan. Bahan baku ini di-supply dari pasar besar Malang yang perolehannya dengan mudah.

\section{Produksi (Peralatan, Kapasitas, in Prosess Kontrol, Nilai Investasi)}

Proses produksi klompen dan sepon memerlukan beberapa peralatan pendukung. Sebagian besar peralatannya didesain dan dimodifikasi para pelaku pengrajin dengan beberapa kali uji coba peralatan, hasil inovasi dari pengalaman-pengelaman sebelumnya. Macam-macam peralatan utama tersebut antara lain:

a. Senggotan plong, yaitu berfungsi untuk melakukan memotong bahan dasar yang khususnya pada spon. Modifikasi plong telah dilakukan beberapa kali dan sampai saat ini masih manual sehingga produksi terbatas. Peralatan yang tradisional ini menjadi andalah para pengrajin dengan kapasitas produksi sangat sedikit sehingga dalam pelaksnaannya secara manual. Jumlah produksi yang dihasilkan pada plong ini setiap 
harinya hanya mencpai 75-110 buah, dan peralatan sering mengalami kerusakan akibat penyusutan (depretiation). Oleh karena itu perlu dilakukan intervensi dalam rangka revisi model peralatan yang memungkinkan untuk peningkatan produksi dari sebelumnya. Komplemen (pelengkap) dari peralatan ini adalah berupa desain sandal sepon dengan ukuran yang bermacam-macam sesuai kebutuhan. Baik pada sepon untuk laki-laki maupun perempuan, perlatan komplemen-pun juga hasil modifikasi dari penga-laman-pengalaman yang mereka lakukan dengan menyesuaikan kebutuhan pasar atas perkembangan dan permintaan konsumen atau pelanggan.

Tabel 1. Matrik Deskripsi Bahan Baku

\begin{tabular}{|l|l|l|l|}
\hline No. & \multicolumn{1}{|c|}{ Aspek } & \multicolumn{1}{c|}{ Kondisi } & \multicolumn{1}{c|}{ Keterangan } \\
\hline 1. & $\begin{array}{l}\text { Asal Bahan } \\
\text { Baku }\end{array}$ & $\begin{array}{l}\text { Perhutani kec.Singosari, } \\
\text { Kec.Karangploso dan Desa } \\
\text { Toyomarto dan/atau tetangga Desa }\end{array}$ & $\begin{array}{l}\text { Sejak tahun 1992, } \\
\text { menjadi pelanggan }\end{array}$ \\
\hline 1. & Kapasitas & $\begin{array}{l}\text { Setiap UKM dapat dipenuhi } 80- \\
100 \text { glondong kayu dengan ukuran } \\
\text { masing-2 glondong 1 m }\end{array}$ & $\begin{array}{l}\text { Minimla ukuran } \\
\text { diamter masing-2 dari } \\
1 \mathrm{~m}^{2}, 15 \mathrm{~cm}\end{array}$ \\
\hline 2. & Spesifikasi & $\begin{array}{l}\text { Spesifikasi kayu didominasi; } \\
\text { sengon mahoni dan basia, tetapi } \\
\text { ada yang memakai kayu jati }\end{array}$ & $\begin{array}{l}\text { Minimal diameter 15 } \\
\text { cm spesifikasi ukuran } \\
\text { srandal 36 }\end{array}$ \\
\hline 3. & Kontinuitas & $\begin{array}{l}\text { Terjaminnya kontinuitas karena } \\
\text { diambil dari 3 lokasi sejak tahun } \\
\text { 1992, kec.karangploso, } \\
\text { kec.singosari dan Perhutani. Dari } \\
\text { 15 UKM dipenuhi sekitar 80-100 } \\
\text { gelondong (potong ukuran 1 m). }\end{array}$ & $\begin{array}{l}\text { Setiap tahun bibit } \\
\text { sengon mahoni dan } \\
\text { basia diberikan secara } \\
\text { Cuma-2 kepada petani } \\
\text { produsen dalam rangka } \\
\text { program sengonisasi. }\end{array}$ \\
\hline 5. & $\begin{array}{l}\text { Bahan } \\
\text { baku }\end{array}$ & $\begin{array}{l}\text { Pelengkap berupa: cat, lem catol, } \\
\text { spon, kain, paku pines, benang, } \\
\text { amplas, soul alas dan kulit. }\end{array}$ & $\begin{array}{l}\text { Kebutuhannya sebesar } \\
\text { 40\% dari keseluruhan }\end{array}$ \\
\hline
\end{tabular}

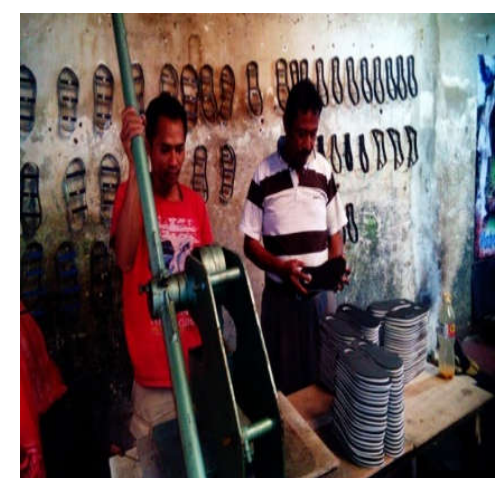

Gambar 2. Senggotan Plong

b. Alat utama laminasi, yaitu dipakan sebagai kelanjutan dari pelaksanaan plong. Kondisi laminasi akan menghasilkan bahan setengah jadi akan akan desaian kain.

c. Mesin Jahit, sebagai pelengkap dari proses produksi untuk finising.

d. Peralatan bahan mentah menjadi bahan setengah jadi berupa: Praser dan penghalus dari semua perlatan ini kapasitas produksi bisa menghasilkan 50-100 pasang tergantung pada masing-masing kesiapan para pekerja. selengkapnya bahan dan peralatan seperti pada Tabel 2. Problem utama yang dihadapi UKM adalah proses produksi serapan tenaga cukup banyak 2-5 orang setiap satu serandal - yang dalam satu hari 
memperoleh sekitar 25 pasang sehingga biaya yang paling membebani adalah untuk upah tenaga kerja. Solusi yang dapat ditawarkan dalam meminimisasi masalah ini adalah modifikasi peralatan semi otomatis yang padat modal khususnya pada proses plong.

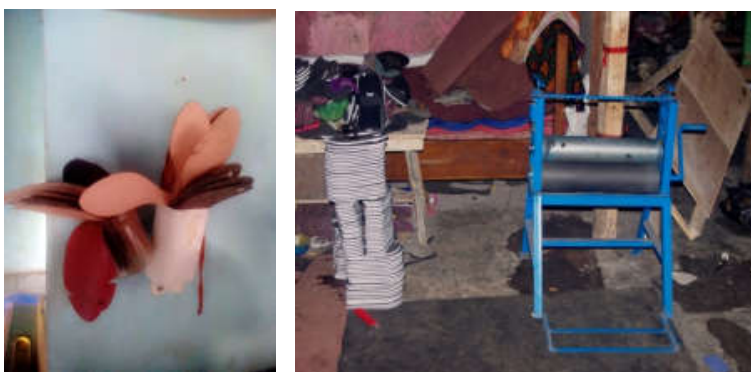

Gambar 3. Alat Laminasi

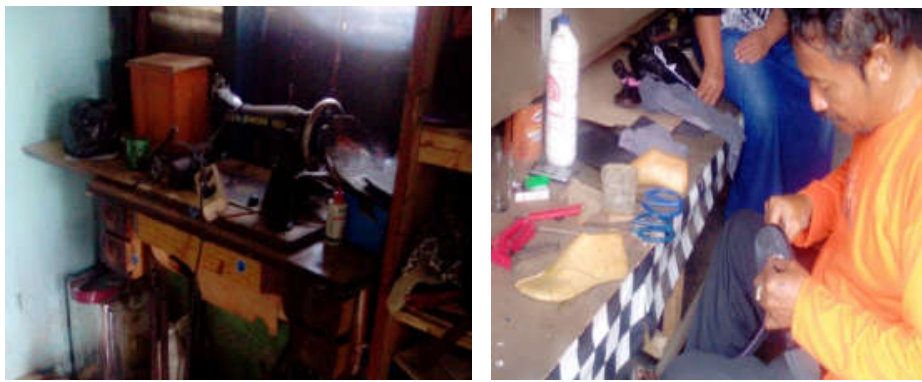

Gambar 4. Mesin Jahit

Tabel 2: Macam Peralatan dan Bahan

\begin{tabular}{|c|c|c|c|}
\hline \multicolumn{2}{|c|}{ Peralatan } & \multicolumn{2}{|r|}{ Bahan Baku } \\
\hline Gergaji Jigsho & Tungku open & Kayu Mahoni & Asal pembelian; perhutani \\
\hline Dinamo amplas & Pembakar & Kayu Basia & Singosari, Kec. Karangploso \\
\hline Kompresor & Tabung LPG & Kayu Jati & dan desa sendiri \\
\hline Gergaji tangan & Paku & Cat & Tambahan bahan: \\
\hline $\begin{array}{l}\text { Klebut (sesuai } \\
\text { ukuran) }\end{array}$ & Talas & Lem kastol & $\begin{array}{l}\text { Benang } \\
\text { Amplas }\end{array}$ \\
\hline Mesin jahit & Tembak Staples & Sepon & Soul alas \\
\hline Plong srandal & Tang & Kain & Kulit, \\
\hline Plong tali & Kuas & Paku pines & Lainnya, sesuai kebutuhan \\
\hline Senggotan & & Benang & \\
\hline
\end{tabular}

\section{Proses (Lay-Out, Jaminan Mutu Produk)}

Proses produksi dalam melakukan penciptaan kelompen dan sandal sepon ini dapat dijelaskaan sebagai berikut kayu basah baik jenis kayu Basia, Mahoni dan/atau kayu Jati yang masih berupa gelondongan, dipotong dalam ukuran 1 meter berupa balok. Hal ini dapat diuraikan sebagai berikut:

1. Pada kayu gelondong dengan ukuran $1 \mathrm{~m}^{2}$ dengan diameter $15 \mathrm{~cm}$ dipotong dengan ukuran $25 \mathrm{~cm}$ yang merupakan batas minimum untuk ukuran orang dewasa.

2. Kayu yang terpotong dengan ukuran $25 \mathrm{~cm}$, dibentuk sesuai dengan ukuran-ukuran sandal yang dikehendaki.

3. Pembentukan dengan pencetakan sandal dengan pemakaian panas $50^{\circ} \mathrm{C}$ agar kayu tidak mudah dimakan rayab atau terbuang. 
4. Melaksanakan pengeringan dengan melakukan oven pada rumah oven yang berukuran $4 \times 4 \mathrm{~m}^{2}$ selama 24 jam, dengan tujuan menghilangkan unsur yang menjadikan bentuk sandal yang tidak simetris.

5. Disaat pada langkah 4 sudah selesai, dilakukan penghalusan menggunakan amplas dengan dinamo penghalus.

6. Selanjutnya dilakukan desain untuk dibentuk sesuai dengan ukuran yang dikehendaki. Dilukis sesuai dengan selera dan pesanan yang menjadi pertimbangan pasar.

7. Pemotongan tali yang mendekati finising $(90 \%)$, dengan pembentukan sesuai dengan ukuran sandal sepon.

\section{Produksi (Jenis, Jumlah, Spesifikasi, Mutu)}

Jenis produki yang dihasilkan oleh UKM ini berdasarkan pada hasil survei awal dan melalui pembimbingan mahasiswa KKN-PPM, sebanyak tiga jenis yang mendominasi yakni sandal sepon, klompen dan tali sandal. Rekapitulasi para pengrajin sebagai mana pada Tabel 3. Masing-masing pengrajin memproduksi didominasi jenis sandal klompen dan spon. Hanya ada lima (5) yang memiliki produk sehngga sekitar 13 UKM yang tidak (belum) memiliki merek, keenganannya disebabkan karena tidak termotivasi untuk berkembang dari jenis yang ada dan mengikuti (menggabung) dari merek yang telah dimiliki oleh tetangga UKM pada produk yang serupa.

Tabel 3: Daftar Kelompok Pengrajin Sandal Klompen dan Sepon, Dusun Sumberawan Desa Toyomarto Kec. Singosari, Kabupaten Malang "Sinar Mandiri", Tahun 2016

\begin{tabular}{|c|l|l|l|c|}
\hline No & \multicolumn{1}{|c|}{ Produksi } & \multicolumn{1}{c|}{ Pemilik } & \multicolumn{1}{c|}{ Alamat } & Merek \\
\hline 1 & Sandal Klompen dan Sepon & H. M. Imam Syafi'i & RT 06/RW 03 & Yustra \\
\hline 2 & Sandal Klompen & Sumadi & RT 01/RW 03 & Reza \\
\hline 3 & Sandal Spon & H. Toha Mubarok & RT 01/RW 03 & Crendy \\
\hline 4 & Sandal Spon & Supriadi & RT 06/RW 03 & \\
\hline 5 & Tali Sandal & Hariadi & RT 01/RW 03 & \\
\hline 6 & Sandal Klompen & Bukori & RT 03/RW 03 & \\
\hline 7 & Sandal Klompen & Muhammad & RT 04/RW 03 & \\
\hline 8 & Sandal Klompen & Darto & RT 07/RW 03 & Prodet \\
\hline 9 & Sandal Spon & Yono & RT 01/RW 03 & \\
\hline 10 & Sandal Spon & Agus & RT 11/RW 03 & \\
\hline 11 & Sandal Klompen & Ngatuji & RT 10/RW 03 & \\
\hline 12 & Sandal Klompen & Wagimin & RT 10/RW 03 & \\
\hline 13 & Sandal Klompen & Markimin & RT 03/RW 03 & \\
\hline 14 & Sandal Klompen & Riamin & RT 06/RW 03 & \\
\hline 15 & Sandal Spon & H. Eko & RT 06/RW 03 & Joker's \\
\hline 16 & Sandal Spon & Durokhim & RT 04/RW 03 & \\
\hline 17 & Tali Sandal & Saiku & RT 06/RW 03 & \\
\hline 18 & Sandal Klompen & Sutrisno & RT 01/RW 03 & \\
\hline
\end{tabular}

Dasar yang dipakai dalam analisis situasi pada usulan ini adalah pada dua UKM yaitu milik bapak Darto dan bapak H. Imam Syafi'i dengan nama produksi 'Prodet' dan 'Yustra', yang representatif pada sandal klompen dan sepon. Jumlah produksi yang dihasilkan dari masing-masing UKM rata-rata sebanyak 50-100 pasang, kadang tergantung 
pada pesanan jumlah produksi lebih dari 100. Apalagi pesnannya untuk dikirim ke Jepang mencapai 500 pasang.

Spesifikasi dan mutu produk UKM Desa Toyomarto, satu dengan yang lainnya adalah serupa, sehingga sebanyak 5 dari 6 orang distributor mengatakan sama kuatnya. Demikian juga dari 4 dari konsumen saat diajukan pertanyaan mengatakan mutu dan spesifikasi cukup memberikan kepuasan kepada konsumen. Spesifikasi dan mutu tetap terjaga karena adanya komplemantasi dari bahan baku utama dan bahan baku pembantu.

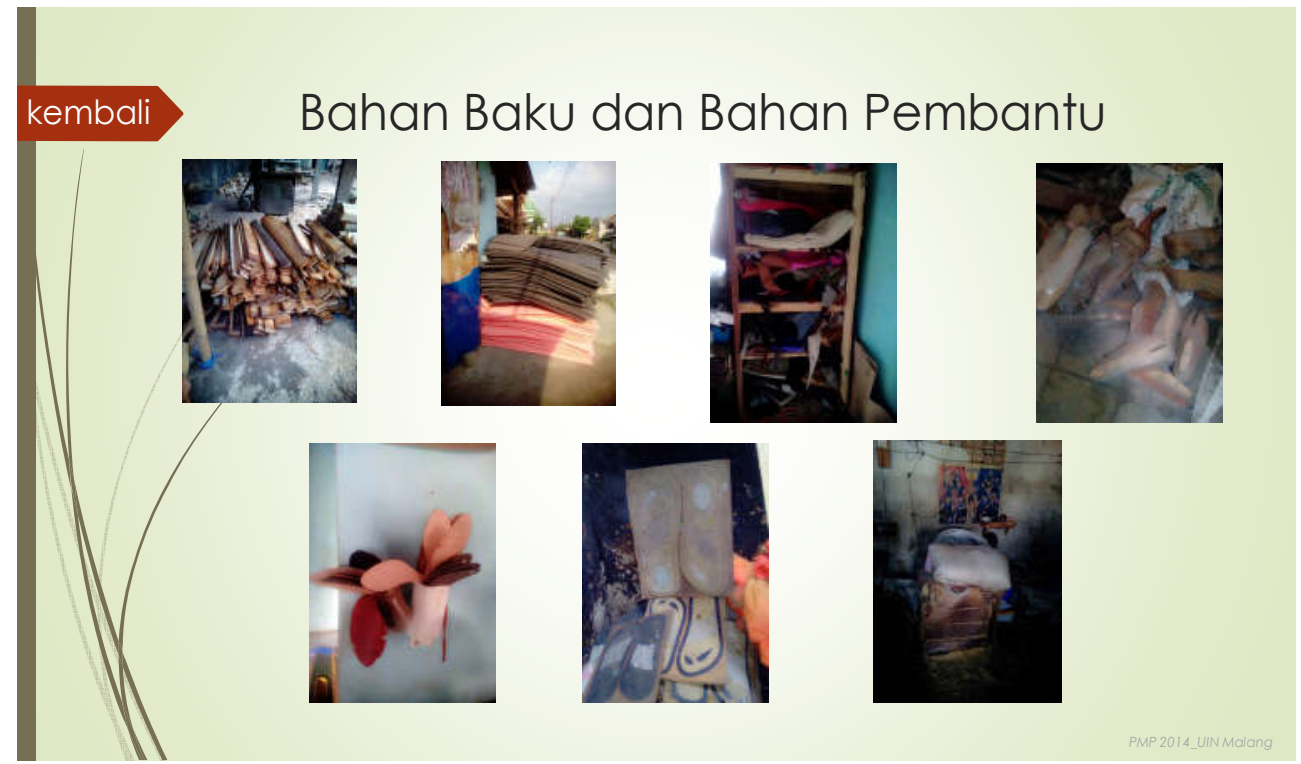

Gambar 5. Bahan Baku dan Bahan Pembantu

\section{Pemasaran (Pasar, Teknik Pemasaran, Harga Jual Produk, Konsumen)}

Dari sejumlah15-18 UKM, ada 5 UKM yang telah memiliki merek, selebihnya hanya memproduksi sandal yang model pemasarannya diikutkan pada UKM yang telah mempunyai merek. Hal ini kurang bagus dari aspek eksistensi usahanya, meskipun secara kualitas dan kuantitas produknya mereka sudah pantas untuk melaksanakan pemasaran sendiri.

Teknik pemasaran dilakukan dengan 'menitipkan' pada UKM lain menjadi budaya yang dapat dilakukan perubahan secara pelan-pelan. Dengan model pemasaran semacam itu harga jual yang diterima produsen seharusnya dapat menutupi biaya produksi pada selisih yang besar- dalam arti keuntungan semakin dapat dirasakan. Harga jual kisaran Rp 35.000 ,- $\mathrm{s} / \mathrm{d} \mathrm{Rp} 40.000$,- dari pedagang pengumpul. Harga dari produsen variasinya tentu di bawah harga jula produk tersebut.

Dengan segmenatasi konsumen yang berada di seluruh Malang raya, luar kabupaten Malang, dan luar propinsi Jawa Timur bahkan hingga ke manca negara, seharusnya pendapatan perolehan para UKM lebih tinggi dibandingkan dengan yang diterima sekarang. Oleh karena itulah tawaran program pemasaran ini dapat dilakukan dengan pendampingan untuk menuju kemandirian hingga pemasaran secara on-line. Uji coba dalam pelaksanaan on-line telah dilaksanakan pada KKN-PPM kolaborasi posdaya berbasis masjid LPPM Unisma dan UIN Maliki yang telah dibuat model blog sebagai berikut:

Sebagian besar pemasarannya ke Jawa Tengah (14\%), Surabaya (26\%), Madura (10\%), Bali (10\%), Malang (20\%) dan sebanyak 10\% dikirim ke kota lainnya di Indonesia. Selain itu, tidak jarang hasil karya pengrajin tersebut telah diekspor ke Jepang (5\%) dan sekitar 5\% ke manca negara lainnya. Di wilayah Malang pemasaran juga dilakukan oleh 
lembaga pemasaran, agen dan belum pernah melakukan pemasaran langsung ke toko-toko karena produk sudah habis diambil oleh agen distributor. Pesaing dari produk ini adalah produksi dalam negeri itu sendiri produk luar negeri adalah cina, namun tingkat kekuatan dan mutu rata-rata konsumen lebih loyal pada produk Daerah Dusun Ngujung sampai saat ini pengusaha yang tergabung dalam UKM 'Sinar Mandiri' ini. Kondisi inilah potensi peluang untuk dikembangkan.

\section{SDM (Kualifikasi dan Jumlah, serta Peluang Training)}

Kualifikasi tenaga kerja dari UKM baik 'Prodet' dan 'Yusta' yang tergabung dalam asosiasi 'Sinar Mandiri' adalah tenaga kerja dari dalam keluarga dan luar keluarga, penyerapan tenaga kerja 6-8 orang sebagai tenaga kerja tetap. Tingkat pendidikn lulusan SD-SMP, bahkan ada yang tidak lulus SD, rata-rata upah yang diberikan per hari Rp.50.000-75.000,- tergantung dari masa kerjanya.

Tenaga dibagi menjadi 3, yaitu (i) tenaga kasar yang menangani bahan baku kayu hingga setengah jadi (50\%), (ii) tenaga menengah (90\%) dan (iii) tenaga finishing (100\%) yang didominasi oleh tenaga kerja wanita. Dengan model kerja yang konvensional dan skill yang dimiliki atas dasar kebiasaan ini, maka peluang traning yang dapat dilakukan sebagai tindak lanjut dalam pertemuan FGD adalah berupa pembukuan (accounting) dan sebagai hasil kesepakatan (agreement) dari peserta kelompok sasaran melakukan pola pendidikan, pelatihan dan pendampingan (P3).

Keterbatasan sumber daya manusia dan minimnya pihak yang peduli terhadap manajerial, dengan bukti belum ada pihak swasta atau pemerintah yang secara intensif membina dan mendampingi pengrajin sandal dai sumberawan, maka hal ini menyebabkan keterbatasan fasilitator dalam pengembangan manajerial usaha, sehingga diperlukan tim asistensi yang berkualitas dan berkelanjutan.

\section{DAMPAK DAN MANFAAT}

Secara umum program ini menghasilkan produk sandal yang berkualitas dengan standar kualitas ekspor, sehingga UKM berkembang dan memiliki segmentasi pasar lebih luas, baik pasar yang domestik maupun pasar luar negeri. Maka hal-hal yang perlu diprioritaskan adalah:

1. Menghasilkan rumah oven karena ukuran masih bekapasitas 100 pasang/24 jam. Dengan menggunakan bahan bakar kayu dan/limbah kayu hasil bekas potongan sandal, inipun efeks sampingannya adalah polusi udara. Modifikasi rumah open dilakukan yang dilengkapi dengan oven putar (burner) hidrolis dengan pengeringan kapasitas tinggi yang dilengkapi dengan hopper feeder yang dapat digunakan untuk proses pengeringan yang efektif dari segi tenaga juga lebih efisien,biaya lebih bisa ditekan, dengan estimasi $2 \mathrm{x}$ lipat hasil dari semula.

2. Optimalnya cetak desain dengan sistem manual yang dapat ditingkat dengan penggarak dinamo menjadi 3 kali lipatnya. Modifikasi dilakukan dengan menambah ukuran cetak yang digerakkan mesin berkekuatan 10 PK pada tekanan $700 \mathrm{rpm}$.

3. Optimalnya manajemen SDM dengan sistem insindetil dan keluarga. SDM yang akan dioptimalkan dengan progran P3 dengan materi perencanaan, keorganisasian, pelaksanaan dan kontrol (POAC). Spesialisasi tenaga akan terlihat pasca P3 sesuai dengan masing-masing job deskripsinya.

4. Memunculkan publikasi hasil kegiatan dalam bentuk teknologi tepat guna (TTG) dan/atau jurnal imliah, disamping dilakukan desiminasi hasil kegiatan.

5. Semua modifikasi dalam upaya perubahan tentunya menyesuaikan dengan kondisi dan kebutuhan kelompok sasaran yang tidak akan merubah teknologi yang mereka miliki.

Penataan manajeman pada pembukuan dan pemasaran dengan segala aspeknya termasuk pemasaran dengan uji coba sistem on-line.

1. Menghasilkan buku perencanaan anggaran, maka perlu melalui dengan pola P3. 
2. Menghasilkan model manajemen biaya, maka perlu dilakukan dengan sistem tradisional dan balance scorecard.

3. Menghasilkan pembuatan laporan keuangan sehingga untuk menetupi perlu dilakukan model basis ETAP (Entitas tanpa akuntabilitas publik).

4. Kurang optimalnya pelaporan pajak: PP No. 46 tahun 2013, pajak orang pribadi yang mempunyai usaha.

5. Manajemen keuangan amat sangat sederhana, maka perlu dilakukan sistem pembiayaan, analisa laporan keuangan.

6. Masih rendahnya strategi pemasaran: packing produk yang lebih menarik sesuai kebutuhan dengan ekspansi pasar melalui penjajakan sistem pemasaran on-line.

\section{KESIMPULAN}

Secara umum program ini menghasilkan produk sandal yang berkualitas dengan standar kualitas ekspor, sehingga UKM berkembang dan memiliki segmentasi pasar lebih luas, baik pasar yang domestik maupun pasar luar negeri. Penataan manajeman pada pembukuan dan pemasaran dengan segala aspeknya termasuk pemasaran dengan uji coba sistem on-line.

\section{UCAPAN TERIMA KASIH}

Ucapan terima kasih disampaikan kepada LPPM UIN Maulana Malik Ibrahim, Malang dan LPPM Universitas Islam Malang atas dukungan dan terselenggaranya kegiatan ini. Tidak lupa diucapkan terima kasih kepada para mitra dan pihak-pihak terkait sehingga kegiatan ini dapat berjalan dengan baik.

\section{REFERENSI}

Andriani, S. and Mu'is, A. (2017) 'Manajerial Asistant Usaha Kecil Menengah Menuju Terwujudnya Destinasi Wisata di Kecamatan Singosari Kabupaten Malang', EL MUHASABA: Jurnal Akuntansi (e-journal), 8(1), pp. 67-87.

Ennis, B. and Litster, J. (1996) 'Granulation and coating technologies for high value-added industries', Client in-house short course, E\&G Associates: Section, 3.

Kusumandyoko, T. C. and Abidin, M. R. (2017) 'Perancangan Media Berbasis Teknologi, Informasi dan Komunikasi (TIK) untuk Unit Pengelola Kegiatan (UPK) Kendedes di Kecamatan Singosari Kabupaten Malang', in. Seminar Nasional Seni dan Desain 2017, State University of Surabaya, pp. 437-443.

Mahfudz, M. (2020) 'Responsi Masyarakat Dampingan Pada Inovasi Program Rumah Pangan Lestari Melalui KKN-PPM Unisma Malang', Jurnal Aplikasi Dan Inovasi Ipteks SOLIDITAS, 3(1), pp. 1-5.

Mansur, M., Machfudz, M. and Widarko, A. (2017) 'Revitalization of SMEs'creative Businesses in Indonesia to Face Asean Economic Free Trade', IJEM (International Journal of Engineering And Management), 1(2), pp. 33-39.

Rofii, F., Hunaini, F. and Tjahjono, N. (2018) 'Pembuatan Alat Pembelah Kayu dan Penyerut Bambu Pada Kelompok Usaha Pengrajin Sangkar Burung di Desa Toyomarto Kecamatan Singosari Kabupaten Malang,, Jurnal Pengabdian Kepada Masyarakat, 24(2), pp. 637-643.

Widiastuti, O. and RS, I. T. (2018) 'IbM Kelompok Pengrajin Sandal Klompen dan Sandal Spon di Desa Toyomarto Singosari', Jurnal Dedikasi, 15. 